\title{
Pleistocene(?) and Holocene Fluvial History of Uphapee Creek, Macon County, Alabama
}

G E O L O G I C A L S U R V E Y B U L L E T I N 115222

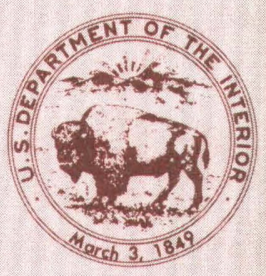





\section{Pleistocene(?) and Holocene Fluvial History of Uphapee Creek, Macon County, Alabama}

By HELAINE W. MARKEWICH and RAYMOND A. CHRISTOPHER

G E O L O G I C A L S U R V E Y B U L L E T I N 15252

A paleoenvironmental and paleoclimatic

reconstruction of Holocene

sedimentation and incision in an

upper Coastal Plain stream valley

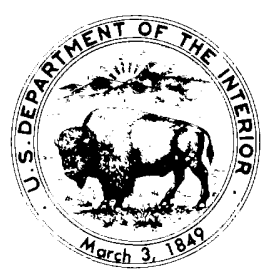




\title{
UNITED STATES DEPARTMENT OF THE INTERIOR
}

\author{
JAMES G. WATT, Secretary \\ GEOLOGICAL SURVEY \\ Dallas L. Peck, Director
}

\section{Library of Congress Cataloging in Publication Data}

Markewich, Helaine W.

Pleistocene(?) and Holocene fluvial history of Uphapee Creek, Macon County, Alabama.

(Geological Survey bulletin ; 1522)

Bibliography: $\mathrm{p}$.

Supt. of Docs. no.: I 19.3:1522

1. Geology, Stratigraphic-Quaternary. 2. Geology-Alabama-Uphapee Creek watershed. 3. Terraces (Geology)-Alabama-Uphapee Creek watershed. I. Christopher, Raymond A. II. Title. III. Series.

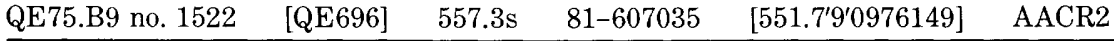




\section{CONTENTS}

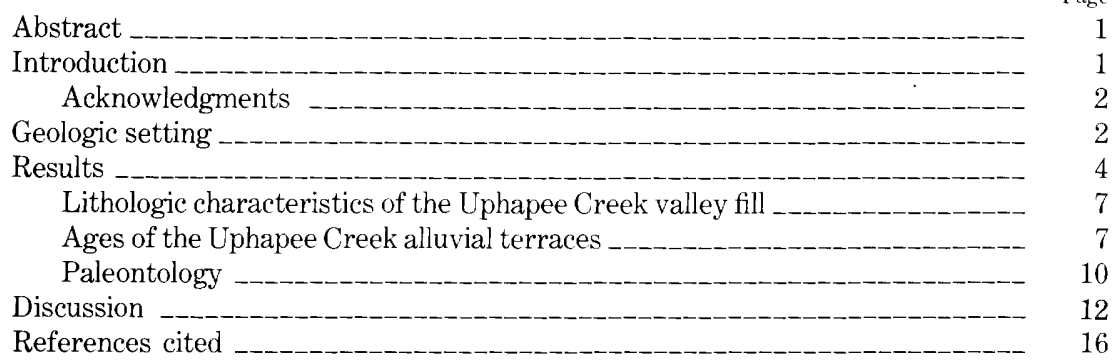

\section{ILLUSTRATIONS}

FIGURE 1. Index map showing major rivers and streams between Auburn and Montgomery, Ala., and outcrop of Piedmont crystalline rocks and sediments of Late Cretaceous age

2. Geologic map showing terraces along Uphapee Creek, cross-section lines, and exposures

3 , 4. Photographs showing-

3 . Three lithologies composing the $a_{3}$ valley fill at locality $M-5$

4. Clay lens containing plant megafossils in alluvium of at terrace

5. Cross-valley profiles showing outcrop pattern of alluvial terraces along Uphapee Creek

6. Photograph along Uphapee Creek and contact between gravelly alluvium of at ${ }_{1}$ terrace and red kaolinitic clay of Upper Cretaceous Tuscaloosa Group

\section{TABLES}

TABLE 1. Characteristics of the present flood plain and the three terraces identified along Uphapee Creek, Macon County, Ala., and of the alluvium underlying the present flood plain and two of the three terraces identified along Uphapee Creek, Macon County, Ala.

2. Relative frequency data for the microflora contained in carbonaceous clay of the at $t_{1}$ valley fill of Uphapee Creek and its stratigraphic equivalent from the Tallapoosa River

3. Occurrence of plant megafossils in carbonaceous clay incorporated in the at $_{1}$ valley fill of Uphapee Creek 


\section{CONVERSION FACTORS}

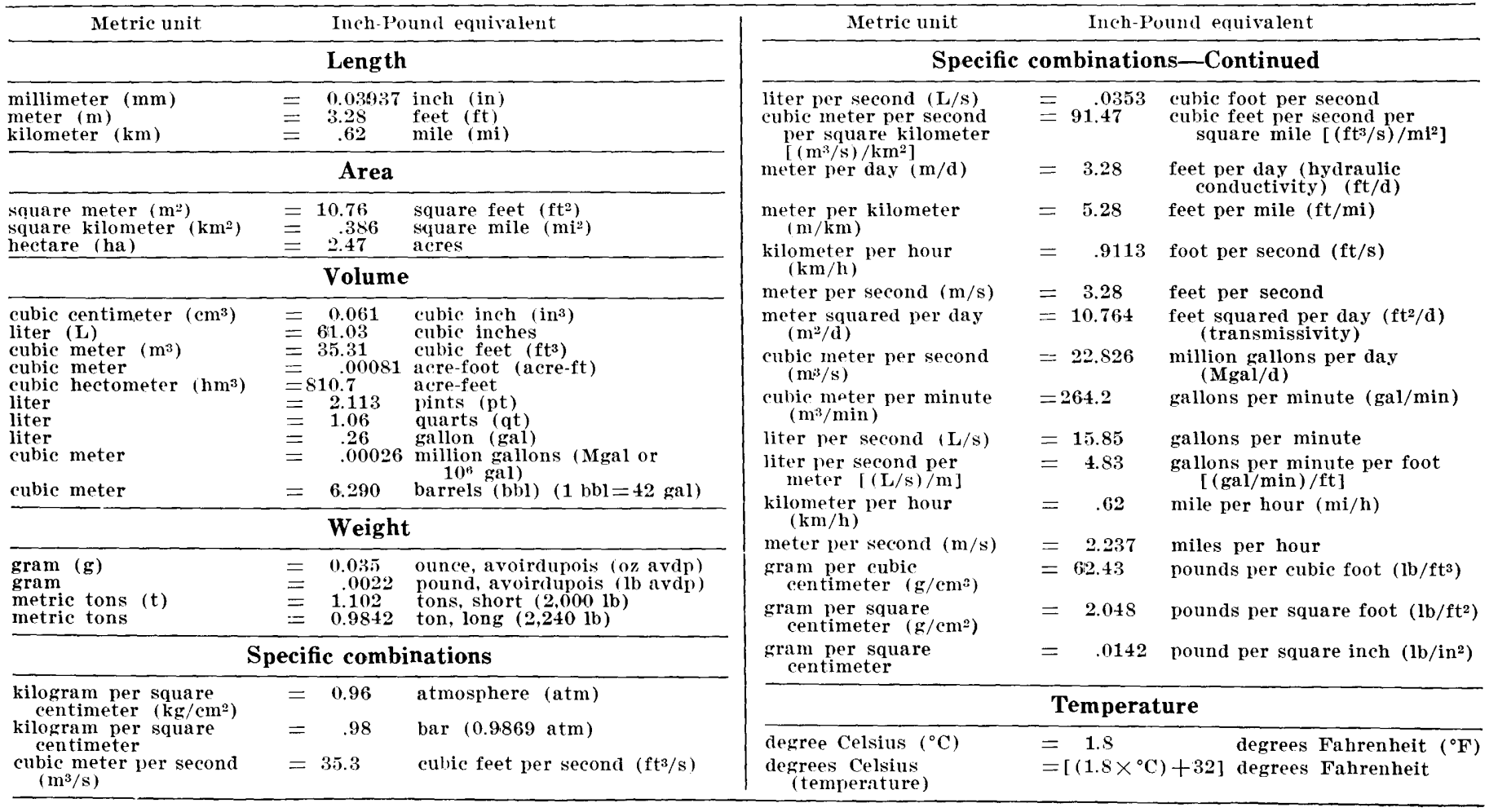




\title{
PLEISTOCENE(?) AND HOLOGENE FLUVIAL HISTORY OF UPHAPEE CREEK, MACON COUNTY, ALABAMA
}

\author{
By Helaine W. Markewich and Raymond A. Christopher
}

\begin{abstract}
Uphapee Creek, Macon County, Ala., a fourth-order stream of the Mobile River basin, was chosen as a test drainage for a first attempt at reconstructing the Pleistocene and Holocene history of a stream in the Coastal Plain province of the Southeastern United States. Two distinct and several poorly defined terraces are present in the valleys of Uphapee Creek and its tributaries. The most extensive and well defined of these is the at terrace, which is adjacent to the stream and which forms the present valley floor. Radiocarbon ages on wood from carbonaceous clay lenses within the at $t_{1}$ terrace alluvium are $6,360 \pm 110$ and $7,520 \pm 110$ years B.P. An age of $27,740 \pm 520$ years B.P., obtained from wood incorporated in a clay pod that was reworked into the at ${ }_{1}$ alluvium, indicates at least one period of deposition and subsequent erosion during the late Pleistocene. Although we cannot determine the age of a distinct but dissected at $t_{3}$ terrace at present, the soil and weathering profiles suggest a possible middle to late Pleistocene period of deposition. We found no evidence for Tertiary-age material within the valley of Uphapee Creek. If Tertiary deposits are present in the area, they are most probably represented by the high-level gravels that cap the Tuscaloosa Group 30 to $50 \mathrm{~m}$ above the present valley floor. Fossils from several localities within the present flood plain and the at $t_{1}$ terrace indicate that the valley fill was deposited under a humid subtropical climatic regime similar to that of the present.
\end{abstract}

\section{INTRODUCTION}

As part of a U.S. Geological Survey (USGS) program designed to evaluate the Quaternary climatic history of the United States, we investigated the fluvial deposits of Uphapee Creek, Macon County, Ala., a fourth-order stream of the Mobile River basin. This investigation was an initial attempt at reconstructing and integrating the geologic and climatic histories of streams in the Coastal Plain physiographic province. A reconnaissance study of several streams in eastern Alabama and western Georgia that were suitable for such a pilot study showed that the alluvial deposits of Uphapee Creek are well exposed along its length and that its valley fill contains several carbonaceous clay lenses and fossil material for paleoecologic, paleoclimatic, and radiometric analyses. 
Our interpretation of the geologic history of Uphapee Creek is based on airphoto interpretation, field investigations, shallow augering, and sedimentary, paleontologic, and radiocarbon analyses. We restricted our study to the alluvial sediments contained within the valley of Uphapee Creek; high-level gravels that cap the surrounding Upper Cretaceous Tuscaloosa Group, $30 \mathrm{~m}$ or more above the present stream, will not be discussed here. Their relationship, if any, to Uphapee Creek is not clear at present.

\section{ACKNOWLEDGMENTS}

We are especially indebted to J. T. Hack, USGS, for the time he spent with us discussing many aspects of fluvial processes. Meyer Rubin, USGS, supplied radiocarbon ages; Donna L. Shipp, George Mason University, Fairfax, Va., identified the plant megafossils; T. J. Carrington, Department of Geology, Auburn University, Auburn, Ala., helped us with the logistics of the fieldwork; and Roy W. Owen, U.S. Steel, Birmingham, Ala., allowed us to use data collected by him while he was a student at Auburn University; for their help we are most grateful.

\section{GEOLOGIC SETTING}

Uphapee Creek is formed by the junction of Chewacla and Opintlocco Creeks, $6.4 \mathrm{~km}$ southeast of Tuskegee, Ala. (fig. 1). The creek joins the Tallapoosa River $19 \mathrm{~km}$ to the west, where the Tallapoosa changes its course from south-southeast to due west. Uphapee Creek is entirely within the Coastal Plain strata of the Upper Cretaceous Tuscaloosa Group, although two of its larger tributaries, Chewacla and Choctafaula Creeks, drain Piedmont crystalline rocks as well as sands and clays of the Tuscaloosa Group. Opintlocco Creek, the other major tributary to Uphapee Creek, drains both the Tuscaloosa Group and the overlying sands and clays of the Upper Cretaceous Eutaw Formation.

The Piedmont rocks drained by tributaries of Uphapee Creek include (1) feldspathic mica schist, biotite gneiss, granite, and augen gneiss of the Wacoochee Belt of Adams (1933), as modified by Bentley and Neathery (1970); (2) mylonite of the Goat Rock and Towaliga fault zones; and (3) schist and gneiss of the Opelika Complex of Bentley and Neathery (1970). The outcrop pattern of these rocks trends northeast, and many lithotypes extend into Georgia. To the southwest, in eastern Alabama, the Piedmont rocks are buried beneath the sands and clays of the Tuscaloosa Group.

The two formations of the Upper Cretaceous Tuscaloosa Group that are recognized in western Alabama (the Coker and overlying Gordo Formations) cannot be discerned in the study area. However, four 

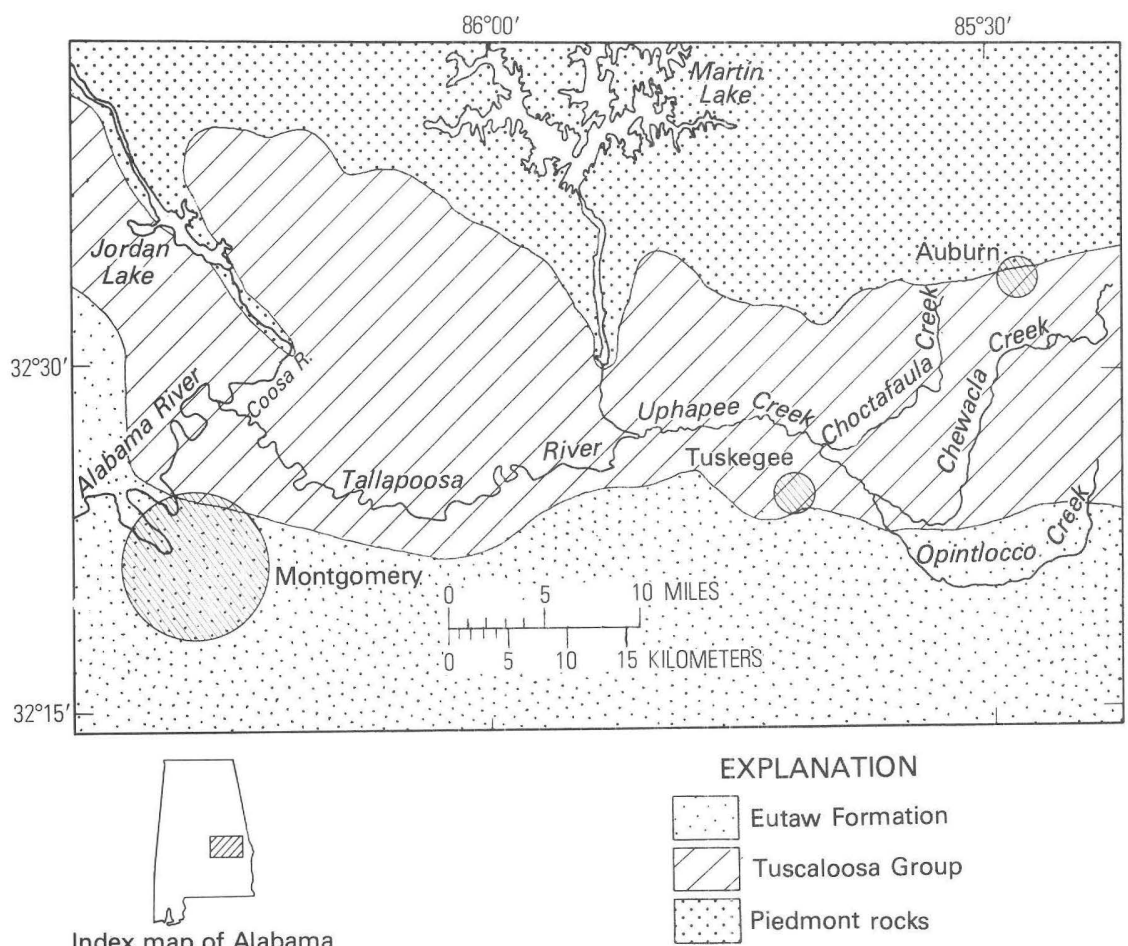

Index map of Alabama

showing area of report

Figure 1.-Index map showing the major rivers and streams beween Auburn and Montgomery, Ala., and the approximate outcrop patterns of the Piedmont crystalline rocks and the sediments of Late Cretaceous age.

distinct lithologies can be differentiated within the Tuscaloosa Group of eastern Alabama: (1) crossbedded feldspathic and kaolinitic sand (the dominant lithology), which commonly contains gravel lenses and stringers; (2) interfingering red-mottled massive kaolinitic clay, commonly containing burrows, and green-mottled micaceous feldspathic medium- to coarse-grained quartz sand (the second most dominant lithologies); (3) and (4) rare occurrences of massive (3) and laminated (4) carbonaceous clay, commonly containing leaf fossils and lignitized, pyritized, or silicified wood.

In eastern Alabama, the Eutaw Formation unconformably overlies the Tuscaloosa Group and consists of massive to crossbedded glauconitic fossiliferous sand alternating with planar to massively bedded marine silt and clay. 


\section{RESULTS}

We mapped three terrace levels within the valley of Uphapee Creek (fig. 2), primarily on the basis of airphoto interpretation and field investigations. Terrace levels $a_{1}$ and $a_{3}$ are geomorphically and lithologically distinct from one another but are relatively homogeneous within themselves; each represents a former flood plain of Uphapee Creek. Terrace $a t_{2}$, restricted to the eastern part of the mapped area, is complex and consists of indistinct, poorly exposed terraces that may represent several depositional periods. Poor exposures and the localized areal extent of the $a_{2}$ terrace prevented us from obtaining enough information to determine the number of depositional and erosional cycles included in this unit and to characterize the sediment of the individual terrace levels. Therefore, we defined the $a_{2}$ terrace simply on the basis of its topographic position; it is a series of small isolated poorly preserved terraces at levels between those of terraces at $t_{1}$ and $a t_{3}$. The most salient characteristics of the present flood plain and the three terraces in the valley of Uphapee Creek are presented in table $1 \mathrm{~A}$ and $\mathrm{B}$.

Uphapee Creek is graded to the Tallapoosa River, and at the junction of these two streams, the present flood plains merge. The flood plain of Uphapee Creek is most extensive in the lower half of the drainage basin.

The topographies of the at $t_{1}$ and $a_{3}$ terraces suggest that each terrace was at one time continuous across the valley as an undissected

TABLE 1A. - Characteristics of the present flood plain and the three terraces identified along Uphapee Creek, Macon County, Ala.

\begin{tabular}{|c|c|c|c|c|c|}
\hline \multirow{2}{*}{ Alluvium } & \multicolumn{2}{|c|}{$\begin{array}{l}\text { Gradient } \\
(\mathrm{m} / \mathrm{km})\end{array}$} & \multirow{2}{*}{ Distribution } & \multirow{2}{*}{\multicolumn{2}{|c|}{$\begin{array}{l}\text { Vertical distance } \\
\text { above present } \\
\text { stream }^{1} \\
(\mathrm{~m})\end{array}$}} \\
\hline & Top & Bottom & & & \\
\hline Present flood plain & 1.0 & No data & $\begin{array}{l}\text { Most extensive along lower half of } \\
\text { Uphapee Creek. Upstream, flood } \\
\text { plain forms small isolated patches. } \\
\text { Maximum width is } 1.0 \mathrm{~km} \text {. } \\
\text { Included in flood-plain deposits are } \\
\text { sandbars associated with the } \\
\text { present stream. }\end{array}$ & $\begin{array}{l}\text { Lowest: } \\
\text { Average: } \\
\text { Highest: }\end{array}$ & $\begin{array}{l}0 \\
1.8 \\
6.1\end{array}$ \\
\hline Terrace at $t_{1}$ & 1.0 & $1.1-1.3$ & $\begin{array}{l}\text { Well-defined, continuous, along the } \\
\text { length of Uphapee Creek. Grades } \\
\text { downstream into terrace along } \\
\text { Tallapoosa River and upstream } \\
\text { into flood plain of Opintlocco and } \\
\text { Chewacla Creeks. Maximum width, } \\
2.1 \mathrm{~km} \text {. }\end{array}$ & $\begin{array}{l}\text { Lowest: } \\
\text { Average: } \\
\text { Highest: }\end{array}$ & $\begin{array}{l}3.7 \\
6.7 \\
9.1\end{array}$ \\
\hline Terrace $\mathrm{at}_{2}$ & Not applicable & Not applicable & $\begin{array}{l}\text { Indistinct levels, restricted to } \\
\text { eastern part of map area. In this } \\
\text { category we have grouped what } \\
\text { may represent several small, } \\
\text { poorly preserved terraces that } \\
\text { have altitudes between those of } \\
\text { terraces at } \text { at }_{1} \text { and at }\end{array}$ & $\begin{array}{l}\text { Lowest: } \\
\text { Highest: }\end{array}$ & $\begin{array}{r}9.1 \\
13.7\end{array}$ \\
\hline Terrace $a_{3}$ & 1.5 & No data & $\begin{array}{l}\text { A series of discontinuous surfaces } \\
\text { that are best developed along the } \\
\text { south valley wall of Uphapee } \\
\text { Creek. Maximum width of terrace, } \\
0.8 \mathrm{~km} \text {. }\end{array}$ & $\begin{array}{l}\text { Lowest: } \\
\text { Average: } \\
\text { Highest: }\end{array}$ & $\begin{array}{l}15.2 \\
19.8 \\
21.3\end{array}$ \\
\hline
\end{tabular}

${ }^{1}$ For terraces measured at four or more localities, we have calculated the lowest, average, and highest vertical distances above the present stream. For terraces measured at fewer than four localities, only the lowest and highest values are provided. Measurements used to determine vertical distance were taken from midpoint of terrace width. 
TABLE 1B. - Characteristics of the alluvium underlying the present flood plain and two of the three terraces identified along Uphapee Creek, Macon County, Ala.

[No data are available for alluvium underlying terrace $\mathrm{at}_{2}$ ]

\begin{tabular}{|c|c|c|c|c|}
\hline Alluvium & $\begin{array}{c}\text { Thickness }{ }^{1} \\
(\mathrm{~m})\end{array}$ & Grain size & Composition & Structures \\
\hline Present flood plain & $\begin{array}{ll}\text { Minimum: } & 2.1 \\
\text { Maximum: } & 2.7\end{array}$ & $\begin{array}{l}\text { Predominantly fine- to } \\
\text { coarse-grained sand } \\
\text { containing local beds } \\
\text { of clay and silt. } \\
\text { Sandbars, included in } \\
\text { this flood plain, also } \\
\text { contain cobble and } \\
\text { small boulder gravel } \\
\text { and an occasional } \\
\text { piece of silicified } \\
\text { Cretaceous wood } \\
\text { measuring as much as } \\
0.5 \text { m in diameter and } \\
1 \mathrm{~m} \text { in length. }\end{array}$ & $\begin{array}{l}\text { Quartz sand and quartzite } \\
\text { gravel and cobbles and } \\
\text { some rock fragments. } \\
\text { Clays are predominantly } \\
\text { kaolinitic, containing } \\
\text { some illite and illite/ } \\
\text { smectite. }\end{array}$ & $\begin{array}{l}\text { Sandbars show high- } \\
\text { angle crossbedding. } \\
\text { No data available } \\
\text { for other deposits } \\
\text { associated with this } \\
\text { terrace. }\end{array}$ \\
\hline Terrace $a t_{1}$ & $\begin{array}{ll}\text { Minimum: } & 2.4 \\
\text { Average: } & 3.7 \\
\text { Maximum: } & 6.1\end{array}$ & $\begin{array}{l}\text { Medium- to coarse- } \\
\text { grained sand, and } \\
\text { pebble to cobble gravel } \\
\text { in approximately equal } \\
\text { volumes. Silt and } \\
\text { clay restricted to } \\
\text { rare lenses at } \\
\text { the base of the unit } \\
\text { and to meander fills } \\
\text { of channels cut } \\
\text { into alluvium. }\end{array}$ & $\begin{array}{l}\text { Quartz sand and quartzite } \\
\text { pebbles and gravel } \\
\text { containing some } \\
\text { rock fragments. Local } \\
\text { lenses of highly } \\
\text { carbonaceous and } \\
\text { fossiliferous clay } \\
\text { are mixed kaolinite and } \\
\text { illite-illite/smectite; } \\
\text { kaolinite dominates. }\end{array}$ & $\begin{array}{l}\text { Crossbedded, fining- } \\
\text { upward sequence, } \\
\text { local planar } \\
\text { bedding near the } \\
\text { top of the alluvium. } \\
\text { Local cut-and-fill. }\end{array}$ \\
\hline Terrace $\mathrm{at}_{3}$ & $\begin{array}{l}\text { Minimum: } 9.1 \\
\text { Maximum: } 10.7\end{array}$ & $\begin{array}{l}\text { Where exposed, alluvium } \\
\text { consists of three } \\
\text { lithologic units. } \\
\text { Basal unit is a } \\
\text { coarse-grained sand } \\
\text { containing lenses of } \\
\text { cobble gravel. Middle } \\
\text { unit is a sandy clay. } \\
\text { Upper unit is a fine- } \\
\text { to medium-, occa- } \\
\text { sionally coarse-grained } \\
\text { sand. }\end{array}$ & $\begin{array}{l}\text { Quartz sand and quartzite } \\
\text { gravels and cobbles } \\
\text { and some rock } \\
\text { fragments. Clay is } \\
\text { kaolinite. }\end{array}$ & $\begin{array}{l}\text { Most sand and gravel } \\
\text { are crossbedded; } \\
\text { clay and some fine- } \\
\text { grained sand are } \\
\text { planar bedded. }\end{array}$ \\
\hline
\end{tabular}

${ }^{1}$ For alluvium underlying terrace $\mathrm{at}_{1}$, which was measured at 18 localities, we have calculated the minimum, average, and maximum thicknesses. For alluvium underlying the flood plain and terrace $a_{3}$, which was measured at fewer than four localities, only the minimum and maximum values are provided.

${ }^{2}$ See discussion in text of radiocarbon ages of alluvium underlying this terrace.

valley fill. Further, the at $t_{1}$ terrace is inset into the valley that was entrenched into the $a_{3}$ alluvial deposits.

The at $t_{1}$ terrace surface is the most extensive and well defined of the three levels and forms most of the valley floor of Uphapee Creek. From its headwaters at the junction of Opintlocco and Chewacla Creeks, Uphapee Creek cuts through the at ${ }_{1}$ valley fill into the underlying Tuscaloosa sand and clay; upstream, the at terrace forms the flood plain of each of these tributaries. The at ${ }_{1}$ terrace grades downstream into an extensive terrace adjacent to the Tallapoosa River. Neither the at ${ }_{2}$ terrace, restricted to the eastern part of the mapped area, nor the $\mathrm{at}_{3}$ terrace, best exposed along the south valley wall, can be easily traced into terraces downstream along the Tallapoosa River or upstream into the valleys of Opintlocco and Chewacla Creeks. 


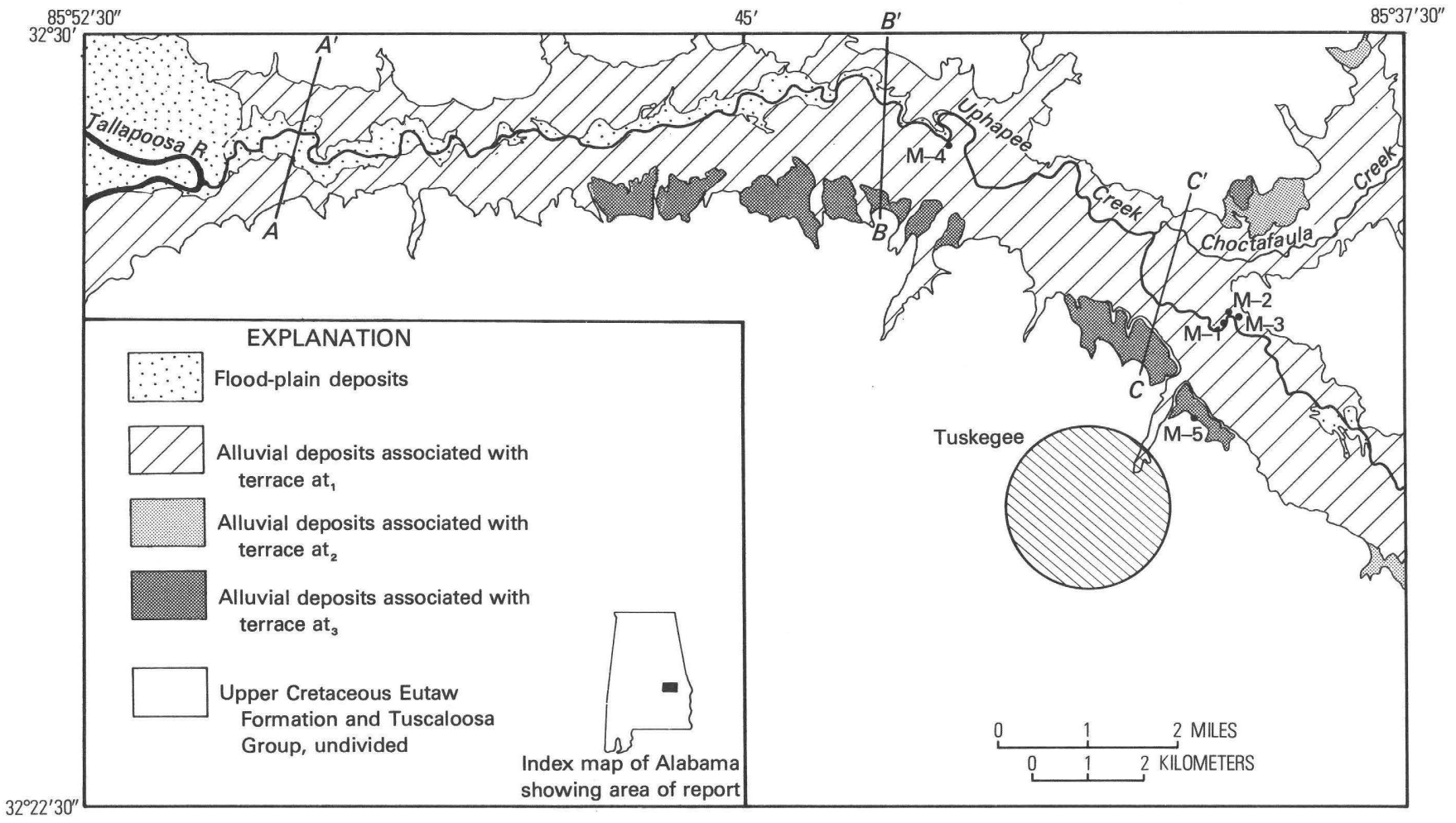




\section{LITHOLOGIC CHARACTERISTICS OF THE UPHAPEE CREEK VALLEY FILL}

The lithology and sedimentary structures of the alluvial sediments of the present flood plain and those of the $\mathrm{at}_{1}$ and $a t_{3}$ terraces are similar. There are no outcrops of the $a t_{2}$ valley fill and therefore no available data. In all places, the sand fraction is dominantly quartz, as are the pebble- and cobble-size clasts; some rock fragments are present in the larger size categories. The clay-size fraction constitutes a small percentage of the alluvium of Uphapee Creek. In fact, only the $a_{3}$ valley fill has distinct clay beds that are continuous for several meters; clay lenses in the flood plain and the at ${ }_{1}$ terrace are thin and discontinuous. X-ray analyses show that kaolinite is the only clay mineral present in the $a_{3}$ alluvium and is the dominant mineral in the floodplain deposits and at $t_{1}$ valley fill. Materials of both the flood plain and

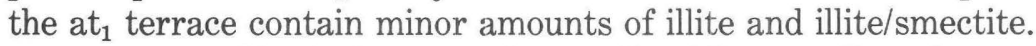

Exposures of both the at $t_{1}$ and $a t_{3}$ valley fill, as well as those of the present flood plain, show fining-upward sequences that grade from crossbedded coarse sand and gravel at the base to planar-bedded medium sand at the top. This fining-upward sequence of sediments is consistent in all examined outcrops and auger samples of the at alluvium. However, one exposure in the at ${ }_{3}$ terrace (fig. 2, loc. M-5) shows an interruption in this sequence; here, a distinct $25 \mathrm{~m}$-long sandy clay bed, as much as $1 \mathrm{~m}$ thick, separates a 3-4-m-thick basal crossbedded coarse-grained sand and cobble gravel from an upper 6-8-m-thick, fine- to medium-grained planar to crossbedded sand (fig. 3). Sand and gravel bars in the flood plain of Uphapee Creek are dominantly coarse-grained quartz sand and pebble-cobble gravel, which have the same crossbedding characteristics that we observed in the basal sand and gravel of the at ${ }_{1}$ and $a t_{3}$ deposits. Fragments of petrified wood as much as $1 \mathrm{~m}$ in diameter have been observed. Both the flood plain and at $t_{1}$ valley fill are extensively mined for sand and gravel. Apparently the clay beds in the $a t_{3}$ alluvium preclude these deposits from being an economic source of sand and gravel.

\section{AGES OF THE UPHAPEE CREEK ALLUVIAL TERRACES}

We have assigned a Holocene age to the at $t_{1}$ valley fill on the basis of radiocarbon analyses, and an early to middle Pleistocene age for the at $t_{3}$ alluvium on the basis of soil development and depth of weathering; hence, the early to middle Pleistocene age assigned to the $a_{3}$ valley fill is subjective and may be modified as the result of further study. We consider the age of the flood plain of Uphapee Creek to be between that of the at $t_{1}$ terrace and the present.

Wood incorporated in the at terrace alluvium yielded radiocarbon ages of $250 \pm 70$ (USGS Radiocarbon Lab. No. W-4282), 6,360 \pm 110 (W-4320), 7,520 $\pm 110(\mathrm{~W}-4319)$, and $27,740 \pm 520(\mathrm{~W}-4281)$ years B.P. 


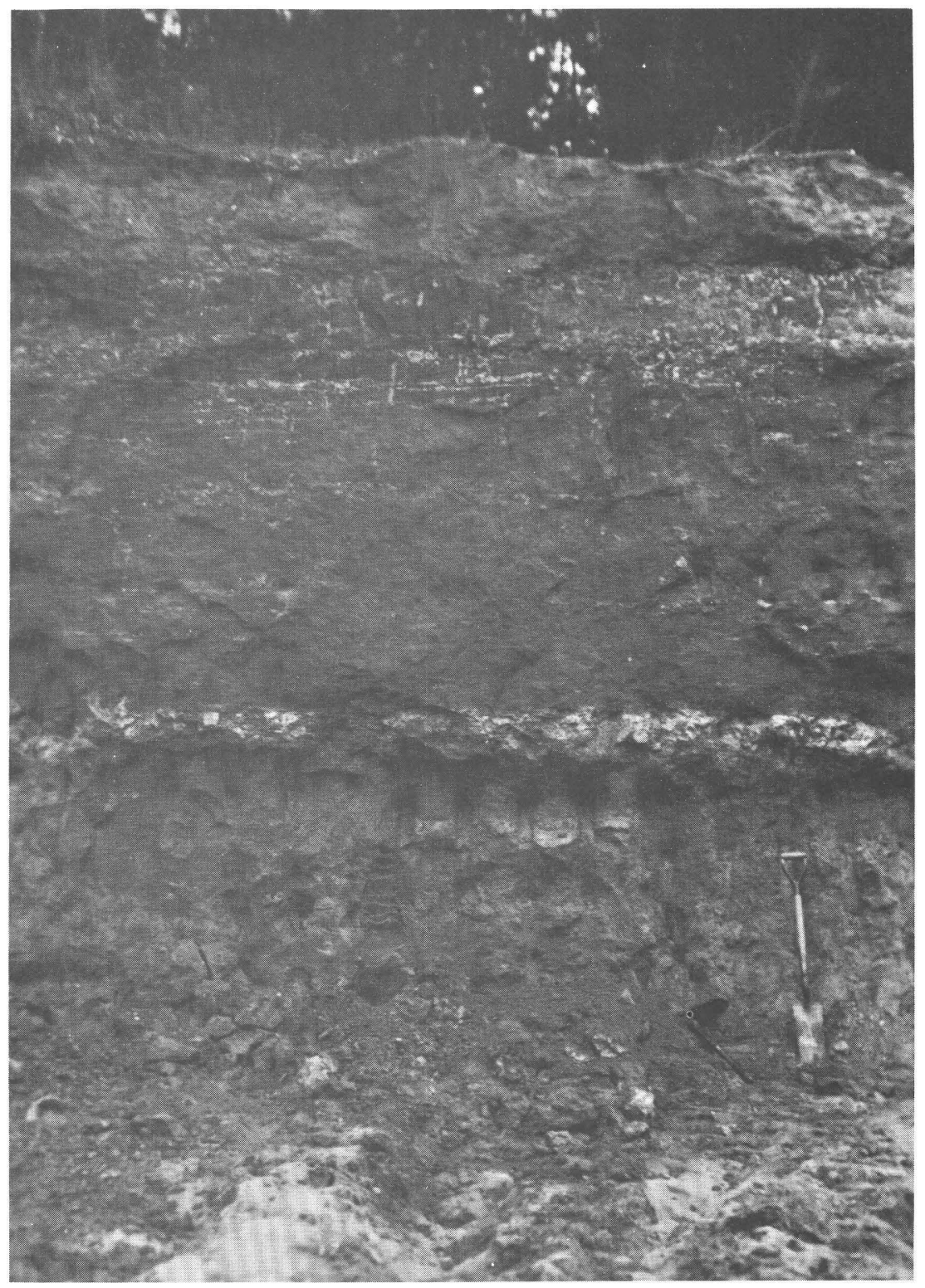

FIGURE 3. - The three lithologies composing the at ${ }_{3}$ valley fill at locality M-5 (fig. 2). 


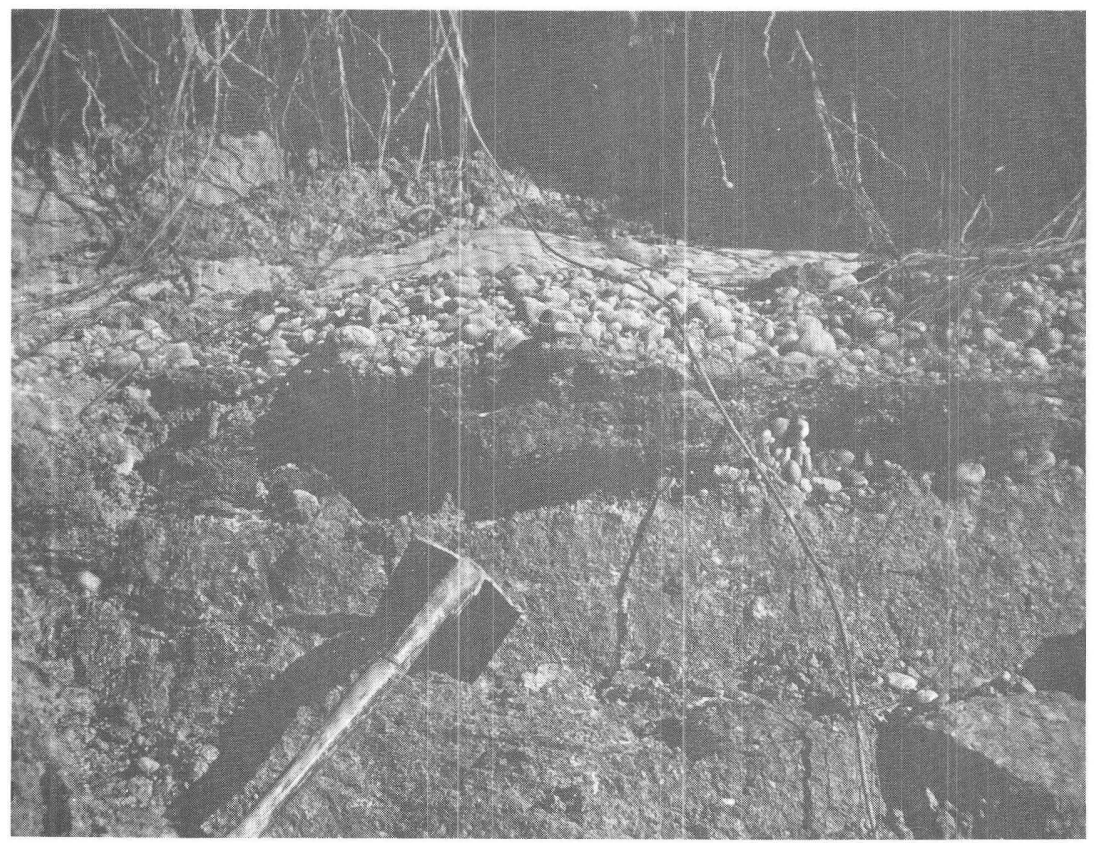

FIGURE 4.-Carbonaceous clay lens $20 \mathrm{~cm}$ thick containing plant megafossils in gravelly alluvium of the at ${ }_{1}$ terrace. Note that the lens is immediately above the contact between the alluvium and the underlying red clay of the Upper Cretaceous Tuscaloosa Group. Outcrop is in the cutbank of Uphapee Creek near Chehaw, Macon County, Ala. (fig. 2, loc. M-4).

(see tables 3 and 4 for radiocarbon ages associated with specific localities and paleobotanical data). Of these four ages, we consider only two (6,360 and 7,520 years B.P.; fig. 2, locs. M-4 and M-1, respectively) to reflect the true age of the at ${ }_{1}$ alluvium. The clays from which the wood was obtained are stratigraphically near the base of the unit and have internal bedding consistent with that of the surrounding deposits (fig. 4). This conclusion is substantiated by three similar radiocarbon ages $-5,260 \pm 90(\mathrm{~W}-4442), 5,470 \pm 100$ (W-4406), and $6,520 \pm 60$ (W-4398) years B.P. - based on wood and disseminated carbonaceous matter from the Tallapoosa River valley fill that grades into the at ${ }_{1}$ terrace of Uphapee Creek. Therefore, the most extensive and well-defined terrace of Uphapee Creek is Holocene in age. The Holocene age for the at $t_{1}$ terrace deposits implies that for Uphapee Creek, the most recent phase of extensive alluvial deposition was between 6,360 and 7,520 years B.P., and the range in age of the at terrace deposits is on the order of 1,000 radiocarbon years.

The radiocarbon age of $250 \pm 70$ years B.P. (fig. 2, loc. M-2) is from wood incorporated in the fill of an abandoned meander cut into the 
alluvium of the at terrace. At this locality, a cross section of this abandoned meander is exposed in a cutbank of the present stream. The vertical distance between the bottom of the present stream channel and the bottom of the meander is $2 \mathrm{~m}$, which implies a maximum downcutting of $2 \mathrm{~m}$ within the last 250 radiocarbon years.

The radiocarbon age of $27,740 \pm 520$ years B.P. (fig. 2, loc. M-3) is from wood incorporated in a pod of carbonaceous clay that we interpret as having been reworked. Our interpretation is based on the lack of internal bedding within the pod and the random orientation of the wood. The radiocarbon age associated with this clay, however, implies alluvial sedimentation at 27,740 years B.P. Incorporation of this clay into the much younger at ${ }_{1}$ alluvium is evidence of an erosional period between the original deposition of the clay and the deposition of the $a t_{1}$ alluvium. We found no other material of this age in the mapped area.

The middle to late Pleistocene age of the alluvium of the $\mathrm{at}_{3}$ terrace is inferred from its weathering profile and soil development (loc. M-5). Whereas sediments of the present flood plain and the at ${ }_{1}$ terrace are weathered to a maximum depth of $2-2.5 \mathrm{~m}$, the $\mathrm{at}_{3}$ terrace is weathered to $10 \mathrm{~m}$. The soil in the at terrace is thin $(90-\mathrm{cm}$-thick pedon) and has only a cambic $\mathrm{B}$ horizon. The soil in the $\mathrm{at}_{3}$ terrace is thick, having a pedon $300 \mathrm{~cm}$ thick; the well-developed textural B horizon is deep red and is $150 \mathrm{~cm}$ thick. Work is in progress relating soil development and degree of weathering to age of the surface in the Middle Atlantic States of New Jersey, Maryland, and Virginia. Our data from Alabama appear to be comparable with those for soils assumed to be middle Pleistocene in age in the Middle Atlantic States, but as no surface has been definitely dated as middle Pleistocene in either region, our interpretation is both preliminary and subjective. The warmer climate of Alabama may produce much more intensely weathered and better developed soils than soils of the same age in similar material in the Middle Atlantic States to the north. Therefore, the at $t_{3}$ valley fill may be as young as late Pleistocene (that is, several hundred thousand years old).

\section{PALEONTOLOGY}

Table 2 gives relative frequencies of spores and pollen from carbonaceous clays incorporated in the Uphapee Creek and Tallapoosa River valley fill; table 3 shows the occurrence of plant megafossils in these deposits.

Both the microfossil and megafossil data show that the at ${ }_{1}$ terrace alluvium (fig. 2, locs. M-1, M-4) of Uphapee Creek and its stratigraphic equivalent along the Tallapoosa River (samples 79W-83a, 79W-121) were deposited under humid subtropical climatic conditions similar to those in the area today. During deposition of the $a_{1}$ valley fill, the flora 
TABLE 2.-Relative frequency data (in percent) for the microflora contained in carbonaceous clay of the at ${ }_{1}$ valley fill of Uphapee Creek and its stratigraphic equivalent from the Tallapoosa River

[+ present but not included in count; n.p., not present]

\begin{tabular}{|c|c|c|c|c|c|c|}
\hline \multirow{3}{*}{ Taxa } & \multicolumn{6}{|c|}{$\begin{array}{c}\text { Locality number and associated radiocarbon age } \\
\text { (in radiocarbon years) }\end{array}$} \\
\hline & \multicolumn{4}{|c|}{ Uphapee Creek } & \multicolumn{2}{|c|}{ Tallapoosa River } \\
\hline & $\begin{array}{c}\mathrm{M}-1 \\
250 \pm 70\end{array}$ & $\begin{array}{c}\mathrm{M}-2 \\
7,520 \pm 110\end{array}$ & $\begin{array}{c}\mathrm{M}-4 \\
6,360 \pm 110\end{array}$ & $\begin{array}{c}\mathrm{M}-3 \\
27,740 \pm 520\end{array}$ & $\begin{array}{c}\overline{79 W}-83 a \\
5,470 \pm 100\end{array}$ & $\begin{array}{l}79 \mathrm{~W}-121 \\
5,260_{ \pm} 90\end{array}$ \\
\hline \multicolumn{7}{|l|}{ Trees and shrubs: } \\
\hline Pinus spp. (pine) & 31.1 & 15.6 & 30.0 & 11.7 & 30.4 & 23.5 \\
\hline Taxodiaceae-Cupressaceae- & & & & & & \\
\hline Taxaceae (Taxodium types) & 3.6 & 2.0 & 1.9 & 11.0 & 1.7 & 3.4 \\
\hline Quercus spp. (oak) & 18.2 & 39.4 & 32.1 & 10.0 & 27.4 & 28.2 \\
\hline Liquidambar spp. (sweet gum) & 3.6 & 1.9 & 5.7 & n.p. & 3.3 & 4.4 \\
\hline Carya spp. (hickory) & 2.3 & 4.8 & 6.4 & 2.3 & 6.0 & 3.0 \\
\hline Betula spp. (birch) & 2.7 & 8.9 & 5.4 & .3 & 5.0 & 6.4 \\
\hline Nyssa spp. (black gum) & 4.6 & 2.5 & 1.3 & n.p. & 2.3 & 1.3 \\
\hline Ulmus spp. (elm) & 2.3 & 1.6 & .3 & n.p. & 1.7 & 5.4 \\
\hline Ostrya-Carpinus (ironwood, & & & & & & \\
\hline hornbeam, hop hornbeam) & 6.0 & 7.3 & 6.0 & n.p. & 2.3 & 3.7 \\
\hline Alnus spp. (alder) & 1.0 & 1.0 & n.p. & .7 & 1.3 & 1.3 \\
\hline Salix spp. (willow) & 5.6 & 1.9 & 1.0 & 1.0 & 1.0 & 1.7 \\
\hline Cornus spp. (dogwood) & + & 1.3 & .6 & n.p. & n.p. & .7 \\
\hline Ilex spp. (holly) & + & n.p. & n.p. & n.p. & .7 & .3 \\
\hline Castanea spp. (chestnut) & n.p. & n.p. & n.p. & .7 & n.p. & .3 \\
\hline Fraxinus spp. (ash) & n.p. & .6 & .6 & n.p. & n.p. & .7 \\
\hline Corylus spp. (hazelnut) & n.p. & n.p. & n.p. & .7 & n.p. & .7 \\
\hline Tilia spp. (basswood) & .3 & .3 & n.p. & n.p. & .7 & n.p. \\
\hline Acer spp. (maple) & 2.0 & .3 & .6 & n.p. & 1.7 & n.p. \\
\hline Ericaceae (heath family) & n.p. & n.p. & n.p. & n.p. & .3 & n.p. \\
\hline Juglans spp. (walnut) & n.p. & .3 & 1.0 & n.p. & n.p. & n.p. \\
\hline \multicolumn{7}{|l|}{ Herbs: } \\
\hline \multicolumn{7}{|l|}{ Compositae, short-spined } \\
\hline (composite family) & 8.6 & .3 & .6 & 23.3 & 1.3 & 2.7 \\
\hline \multicolumn{7}{|l|}{ Compositae, long-spined } \\
\hline (composite family) & n.p. & n.p. & n.p. & 3.7 & .7 & 1.3 \\
\hline Gramineae (grass family) & .3 & n.p. & 6 & .7 & 1.0 & .3 \\
\hline \multicolumn{7}{|l|}{ Chenopodiaceae (goosefoot } \\
\hline family) & .3 & n.p. & n.p. & 1.7 & .7 & .7 \\
\hline \multicolumn{7}{|l|}{ Aquatic plants: } \\
\hline Liliaceae (lily family) & .3 & n.p. & n.p. & n.p. & 1.0 & n.p. \\
\hline \multicolumn{7}{|l|}{ Spores: } \\
\hline Sphagnum spp. (moss) & .3 & n.p. & n.p. & 2.7 & n.p. & n.p. \\
\hline Osmunda spp. (flowering fern) & n.p. & n.p. & .6 & n.p. & n.p. & n.p. \\
\hline Polypodium spp. (polypody fern) & n.p. & n.p. & .6 & n.p. & n.p. & n.p. \\
\hline Sellaginelloides & n.p. & n.p. & n.p. & 8.0 & n.p. & n.p. \\
\hline Indeterminate & 1.7 & 2.5 & n.p. & 8.7 & 2.3 & 3.4 \\
\hline \multicolumn{7}{|l|}{ Algae: } \\
\hline Pseudoschizaea sp & n.p. & n.p. & n.p. & 1.3 & 1.0 & .7 \\
\hline Reworked Cretaceous forms & n.p. & n.p. & n.p. & .7 & n.p. & n.p. \\
\hline Others & 5.0 & 2.9 & 3.8 & 11.0 & 6.0 & 6.8 \\
\hline
\end{tabular}

appears to have been dominated by a pine-oak forest composed primarily of arboreal hardwoods; herbs, aquatic plants, and ferns constitute only a small percentage of both the microflora and megaflora.

Pollen data (table 2) suggest that similar climatic and vegetational conditions may have prevailed as recently as 250 years B.P. (fig. 2, loc. M-2), but at that time, herbaceous plants, specifically the composites, assumed a more dominant role, apparently at the expense of oak. The rise in herbaceous pollen at that time might reflect increased open-field conditions; megafossil data (table 3) suggest, however, that the flora was still dominated by oak. 
TABLE 3.-Occurrence of plant megafossils in carbonaceous clay incorporated in the at $t_{1}$ valley fill of Uphapee Creek

[Analysis by Donna L. Shipp, Department of Botany, George Mason University, Fairfax, Va.; +, present]

\begin{tabular}{|c|c|c|c|}
\hline \multirow[b]{2}{*}{ Taxa } & \multicolumn{3}{|c|}{$\begin{array}{l}\text { Locality number and associated radiocarbon age } \\
\text { (in radiocarbon years) }\end{array}$} \\
\hline & $\begin{array}{c}\mathrm{M}-1 \\
250 \pm 70\end{array}$ & $\begin{array}{c}\mathrm{M}-2 \\
7,520 \pm 110\end{array}$ & $\begin{array}{c}\mathrm{M}-4 \\
6,360 \pm 110\end{array}$ \\
\hline \multicolumn{4}{|l|}{ Trees and shrubs: } \\
\hline Pinus spp. (pine) & + & + & + \\
\hline P. taeda (loblolly pine) & & + & \\
\hline Acer rubrum (red maple) & + & + & + \\
\hline Betula nigra (river birch) & & + & + \\
\hline Fagus grandifolia (large-leaved beech) & & + & + \\
\hline Liriodendron tulipifera (tulip poplar) & & + & \\
\hline Carya tomentosa (mockernut) & & & + \\
\hline Platanus occidentalis (sycamore) & & & + \\
\hline Quercus alba (white oak) & & + & \\
\hline Q. coccinea (scarlet oak) & + & + & + \\
\hline Q. phellos (willow oak) & & + & \\
\hline Q. nigra (water oak) & & + & \\
\hline Q. michauxii (swamp chestnut oak) & & + & \\
\hline Q. stellata (post oak) & & + & \\
\hline Carpinus caroliniana (American hornbeam) & & + & \\
\hline Ilex opaca (American holly) & + & & \\
\hline Salix nigra (black willow) & & + & \\
\hline Fraxinus sp. (ash) _ & & & + \\
\hline Viburnum dentatum (southern arrow-wood) & & & + \\
\hline Ulmus alata (wahoo elm) & & + & \\
\hline \multicolumn{4}{|l|}{ Herbs: } \\
\hline Rhychospora sp. (beak-rush) & & + & \\
\hline
\end{tabular}

Although pine and oak pollen dominate the arboreal pollen in a sample from locality M-3 (radiocarbon age $27,740 \pm 520$ years B.P.), their total percentages are comparatively low; the herbaceous composites account for 27 percent of the assemblage. These data seem to indicate that at the time of deposition, herbaceous plants were far more dominant than they would be 20,000 radiocarbon years later. The microfloral assemblage from this sample can be correlated with Watts' (1973) zone G-4 (the Pinus-Quercus-Herb zone) that was established for Bartow County, northwest Georgia. According to Watts, this zone, dated as older than $29,630 \pm 1,400$ years B.P., suggests a dry prairielike herb-rich grassland that was locally treeless. Although Pinus and Quercus were both present, other tree species are poorly represented.

\section{DISCUSSION}

Our study of the history of Uphapee Creek is an initial attempt at reconstructing the geologic and climatic histories of streams in the southeastern Coastal Plain. Our results demonstrate that a combination of soil studies, palynology, and plant megafossil evidence may provide a basis for interpreting the fluvial history of a part of the eastern Gulf Coastal Plain. Our data suggest that Uphapee Creek has been a 
degrading stream throughout most of its history. The following is a chronology of events during part of the Quaternary in the valley of Uphapee Creek:

1. Incision of the valley of Uphapee Creek into the Tuscaloosa Group as the result of one or more periods of erosion at some time prior to deposition of the $a_{3}$ fill.

2. Deposition of the $\mathrm{at}_{3}$ valley fill, probably during the middle to late Pleistocene. Because of its thickness $(10 \mathrm{~m})$ and the three distinct lithologic units within the fill, we interpret the $a_{3}$ fill as reflecting a minor aggradational phase of Uphapee Creek.

3. Entrenchment through the $a_{3}$ valley fill into the Tuscaloosa Group by the trunk stream (Uphapee Creek), and dissection of the valley fill by lateral (that is, tributary) streams that may have been graded to the $a_{3}$ valley fill prior to this period of entrenchment or that began during this period of downcutting. Some of these tributaries (for example, Choctafaula Creek) may also have cut through the valley fill into the Tuscaloosa Group. During this phase, a sequence of flood plains formed and were abandoned. The earlier ones are represented by the complex at ${ }_{2}$ terrace. The 27,740 years B.P. clay pod probably has been reworked from one of these former flood plains.

4. Deposition of the at $t_{1}$ valley fill.

5. Entrenchment through the at ${ }_{1}$ valley fill downstream from the junction of Chewacla and Opintlocco Creeks.

6. Deposition of the present flood plain. The 250 years B.P. meander fill is included with these deposits.

The lack of data on the history of the valley, prior to deposition of the $\mathrm{at}_{3}$ valley fill and between deposition of the $\mathrm{at}_{3}$ and the at $\mathrm{t}_{1}$ valley fill, indicates that a large part of the Pleistocene record is missing. The few remnants of terrace levels mapped as at ${ }_{2}$ provide our only clues to the history of the valley between entrenchment through the $\mathrm{at}_{3}$ terrace and deposition of the at $t_{1}$ alluvium. However, because the $\mathrm{at}_{2}$ unit provides neither exposures nor radiometric ages, we can say nothing about the timing or extent of the periods of deposition and erosion. The 27,740 years B.P. age for the clay pod reworked into the at $t_{1}$ alluvium suggests at least one period of fluvial deposition in the late Pleistocene. Although the paleontologic evidence indicates periods of fluvial deposition during climatic and ecologic conditions not too different from those at present, we have no evidence to suggest a cause (or causes) for initiation and (or) cessation of downcutting. A suggestion could be made that because the 5,260 and 7,520 years B.P. ages for the at terrace and the 27,740 years B.P. age for the reworked clay pod are in agreement with high stands of sea level (see, for example, Curray, 1965; Milliman and Emery, 1968; Field and others, 1979), then periods 
of fluvial deposition in the valley of Uphapee Creek coincide with intervals of warm humid climate. Although the paleontologic data support the contention that flood-plain formation took place during periods of humid subtropical climatic conditions, we believe that a direct causeand-effect relationship between high stands of sea level and flood-plain formation is spurious because of the limited effect that a rise in base level has on the upstream reaches of a drainage basin (Leopold and Bull, 1979). Therefore, we have not come to a conclusion on the causes of aggradation or degradation in this area.

From cross sections of the valley of Uphapee Creek (fig. 5), which are based on field mapping and shallow augering, it appears that Uphapee Creek cut through its alluvium into the underlying Tuscaloosa sand and clay during each episode of downcutting. Exposures at the base of the present flood plain and at the base of the at ${ }_{3}$ valley fill are too few for us to determine the nature of the contacts, but the contact between the at valley fill and the Tuscaloosa red clay is essentially planar, having few or none of the irregularities usually associated with streambeds (fig. 6). This planar surface suggests periods of denudation that produced a' strath or bedrock terrace prior to deposition of the valley fill.

The varying sizes of meander scrolls on the at terrace suggest periods of greater and lesser discharge than that of present Uphapee Creek. However, calculation of the stream-gradient index (of Hack, 1973; a measure of the competence of a given reach of a stream) for the present Uphapee Creek results in a value of 71 gradient-meters. According to Hack (oral commun., 1979), this value suggests a stream capable of transporting, and therefore depositing, even the largest of the alluvial materials (cobbles as much as $10 \mathrm{~cm}$ in diameter) incorporated in the Uphapee Creek terrace alluvium.

Our paleontologic, radiocarbon, sedimentologic, and pedologic data suggest that the valley of Uphapee Creek formed during the Quaternary Period; we have yet to demonstrate that any fluvial sediments are of Tertiary age. In fact, the extensive and well-defined terrace adjacent to both Uphapee Creek and the Tallapoosa River is middle Holocene in age. Similar ages are reported from the lower Tombigbee River terrace in southeastern Mississippi (F. L. Nials, oral commun., 1979). We consider the oldest terrace associated with Uphapee Creek, at ${ }_{3}$, to be middle to late Pleistocene in age. If there are any Tertiary deposits within the valley of Uphapee Creek, they are represented by the erosional remnants of gravel at several levels 30 to $50 \mathrm{~m}$ above the present stream. The highest deposits of these gravels cap the divide between Uphapee Creek and Calebee Creek to the south; as yet, we have no evidence that they are related in any way to the formation of Uphapee Creek. Our results provide the basis for correlation of the Holocene, Pleistocene, and possible Tertiary alluvial deposits westward into the valley of the Tallapoosa River. 

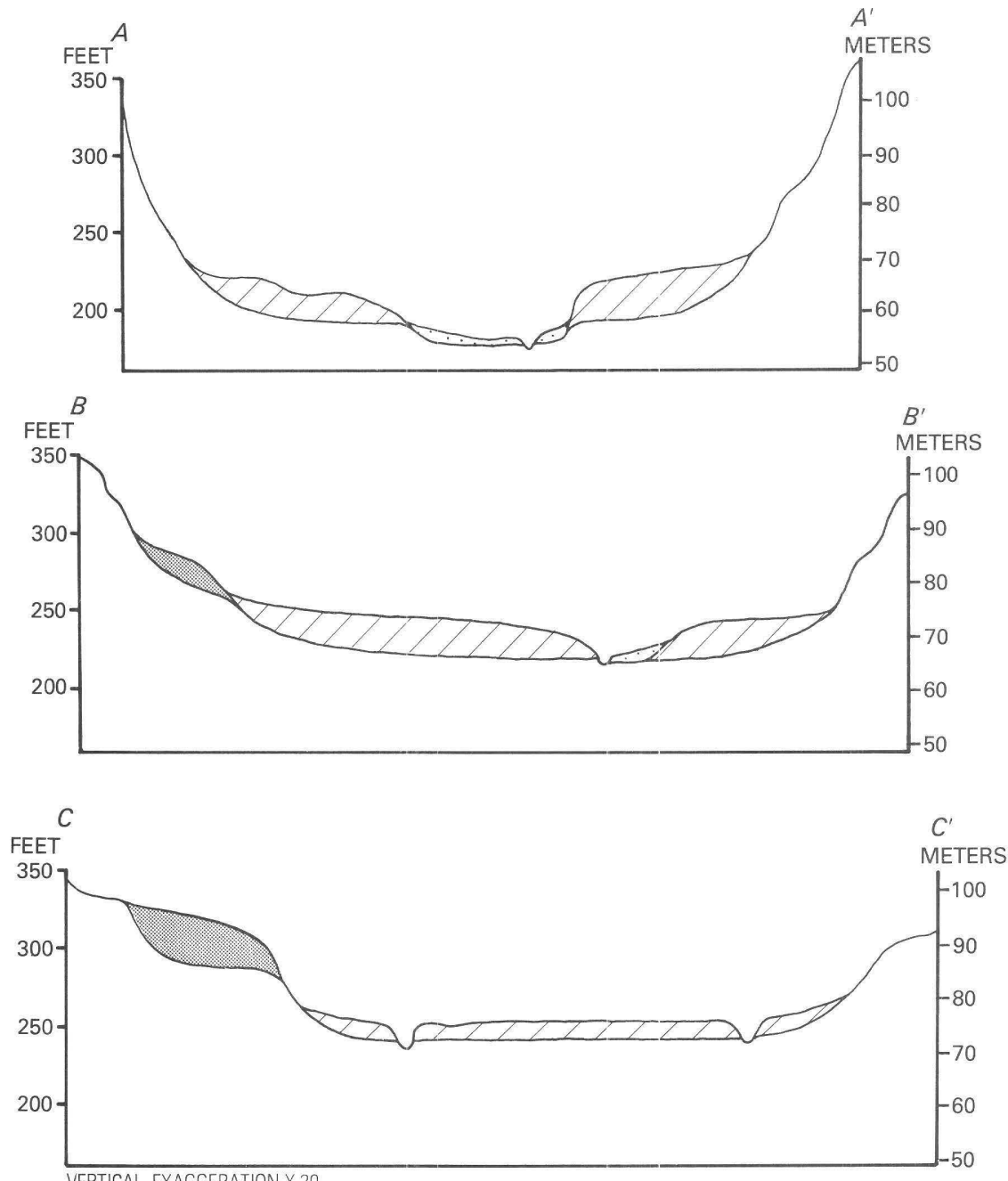

VERTICAL EXAGGERATION X20

\section{EXPLANATION}

Flood-plain deposits

Alluvial deposits underlying terrace at,

Alluvial deposits underlying terrace $\mathrm{at}_{3}$

Upper Cretaceous Eutaw Formation and Tuscaloosa Group, undividec

Figure 5. - Cross-valley profiles showing the outcrop pattern of the alluvial terraces along Uphapee Creek. Locations of the profiles are shown on figure $2 ; A-A^{\prime}$ is just upstream from the junction of Uphapee Creek and the Tallapoosa River. 


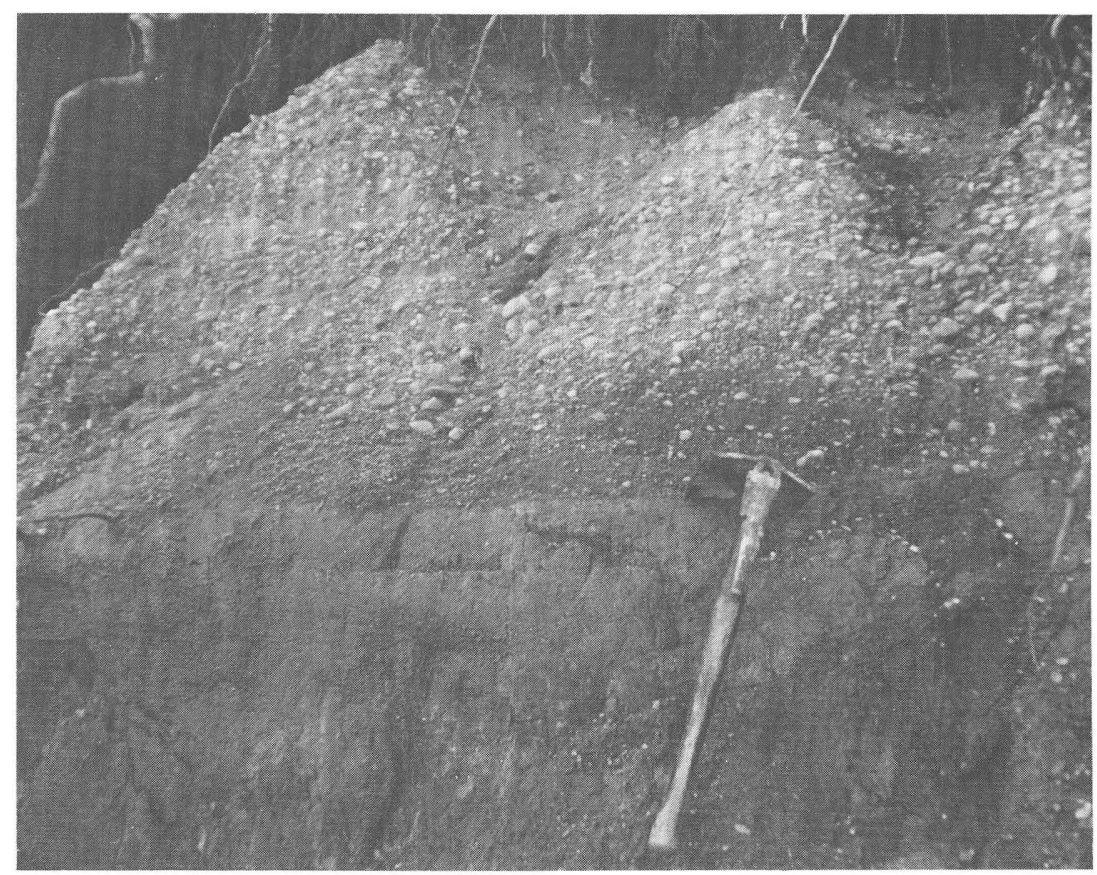

Figure 6. - View along Uphapee Creek, Macon County, Ala. Head of the shovel is at the contact between the gravelly alluvium of the at ${ }_{1}$ terrace (above) and the red kaolinitic clay of the Upper Cretaceous Tuscaloosa Group (below).

\section{REFERENCES CITED}

Adams, G. I., 1933, General geology of the crystallines of Alabama: Journal of Geology, v. 41, no. 2, p. $159-173$.

Bentley, R. D., and Neathery, T. L., 1970, Geology of the Brevard fault zone and related rocks of the Inner Piedmont of Alabama - Alabama Geological Society Field Trip, 8th Annual, 1970, Guidebook: University, Ala., Alabama Geological Society, 1970, 119 p.

Copeland, C. W., 1968, Geology of the Alabama Coastal Plain: Alabama Geological Survey Circular 47, $97 \mathrm{p}$.

Curray, J. R., 1965, Late Quaternary history, continental shelves of the United States, in Wright, H. E., Jr., and Frey, D. G., eds., The Quaternary of the United States: Princeton, N.J., Princeton University Press, p. 723-735.

Field, M. E., Meisburger, E. P., Stanley, E. A., and Williams, S. G., 1979, Upper Quaternary peat deposits on the Atlantic inner shelf of the United States: Geological Society of America Bulletin, v. 90, no. 7, pt. I, p. I-618 to I-628.

Hack, J. T., 1973, Stream-profile analysis and stream-gradient index: U.S. Geological Survey Journal of Research, v. 1, no. 4, p. 421-429.

Leopold, L. B., and Bull, W. B., 1979, Base level, aggradation, and grade: American Philosophical Society Proceedings, v. 123, no. 3, p. 168-202.

Milliman, J. D., and Emery, K. O., 1968, Sea levels during the past 35,000 years: Science, v. 162 , no. 3858, p. $1121-1123$.

Watts, W. A., 1973, The vegetation record of a mid-Wisconsin interstadial in northwest Georgia: Quaternary Research, v. 3, no. 2, p. 257-268.

\&.S. GOVERNMENT PRINTING OFFICE: 1982-361-614/6 

